\title{
Analysis on Children Robot Interaction with Dramatic Playes for Better Augmented Reality
}

\author{
Jeong-Hye Han*
}

\begin{abstract}
This study highlights the effectiveness of analyzing the feelings children have when interacting with robots in a dramatic play setting using augmented reality in Human Robot Interaction (HRI). Existing dramatic play activities using robots by QR-markers were edited, and their weaknesses have been corrected so that children could interact more effectively with robots. Additionally, children's levels of interest and engagement in dramatic play activities, the accuracy of robotic props, and the smartness of robots were analyzed throughout children's interactions during such activities using augmented reality. Younger participants were more likely to find robots interesting and intelligent, and participants with no previous experience with robots had relatively higher levels of interest in robots and tended to notice changes in robots' costumes.
\end{abstract}

Keywords: Augmented Reality, Dramatic Play, QR-markers, Children-Robot Interaction, Human-Robot Interaction

\section{어린이 극놀이 증강현실감을 위한 아동로봇상호작용 분석}

\section{한정혜*}

\section{요 약}

이 연구에서는 인간과로봇상호작용(HRI)에서 유아들을 대상으로 로봇을 활용한 증강현실 극놀이 실 험을 통하여 아동들이 느끼는 상호작용 분석을 제시하고자 한다. 기존의 극놀이 로봇콘텐츠를 아동들이 상호작용하기에 편하도록 $\mathrm{QR}$ 마커의 단점을 개선하여 개발하였다. 또한 로봇을 활용한 증강현실 극놀 이에 대해서 로봇 극놀이에 대한 흥미, 로봇분장의 적절성, 로봇이 똑똑해 보이는 정도, 극놀이에 몰입 감에 대한 아동의 반응을 분석하여 보았다. 나이가 어릴수록 재미가 높고, 로봇이 똑똑하다고 생각하였 고 로봇 사용경험이 없는 아이들이 상대적 흥미가 높고, 로봇분장에 대해서는 로봇사용 경험 있는 아이 들이 차이를 인지하는 것으로 나타났다.

키워드 : 증강현실, 극놀이, QR 마커, 아동과로봇상호작용(CRI), 인간과로봇상호작용(HRI)

\section{Introduction}

There have been many field trial studies

※Corresponding Author: Jeonghye Han

Received: December 10, 2016

Revised : December 26, 2016

Accepted : Decembe 30, 2016

* Dept. of Computer Education, Cheongju National

University of Education

email: hanjh@cje.ac.kr aimed at utilizing robots in an educational setting, especially with the intention to prove the educational effectiveness of using robots in foreign language education, dramatic play settings, and other fields [2, 3, 4]. Using robots and virtual reality (VR), it was showed the effectiveness of using robot-assisted treadmill training in a VR-based soccer scenario with young patients undergoing rehabilitation [1]. It was proved that dramatic play in a robot-mediated condition showed 
higher levels of satisfaction, interactive engagement, and empathy than dramatic play with computer-mediated conditions [2]. An instructional model and robot contents were developed to produce robot-based dramatic plays for children using augmented reality [4, 5].

In this study, the contents of robot-based dramatic play activities using augmented reality were modified so that children's faces were not covered. Additionally, robots were dressed in a relevant way, and effects on children's interaction with them were analyzed.

\section{Developing robot contents for dramatic play}

Existing content in dramatic play using robots requires players to wear large $\mathrm{QR}$ markers when engaging in an activity [2, 3], causing distractions for children. A QR code marker on the head (Figure 1a) obstructs the image of a child's face and is inconvenient. Therefore, modifications were made so that children could hold markers (Figure 1b) or post markers on their $\mathrm{t}$-shirts (Figure 1c) to focus better during the activity.
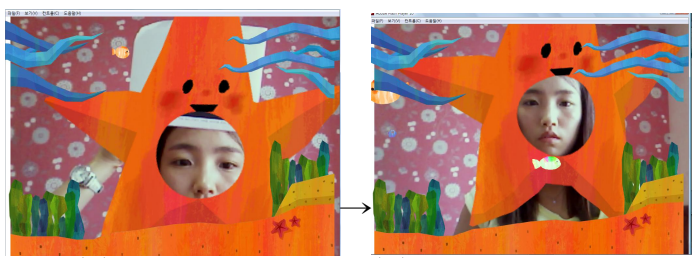

(a) Before adjusted (b) After adjusted

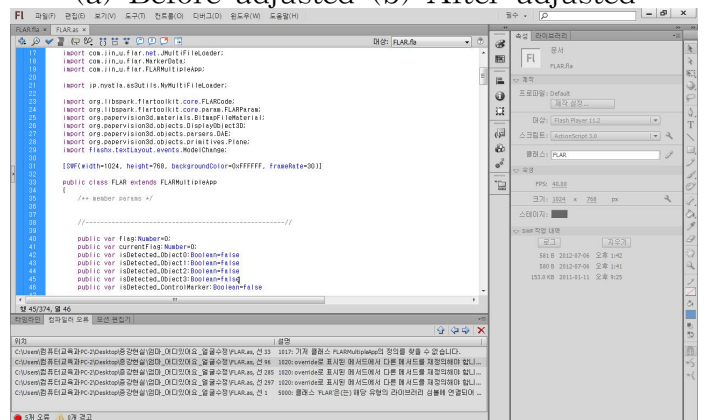

(c)Scene of Authoring tool in robot script

(Figure 1) Contents and Authoring Tool
(Figure 2) depicts the final product of the dramatic play system using robots after modifications were implemented. Robots and children were positioned $1.5 \mathrm{~m}$ apart and filmed for presentation on a TV screen. The bottom left image depicts the scene before the marker location was changed, and the image on the right shows the situation after the marker location was designated as the chest.

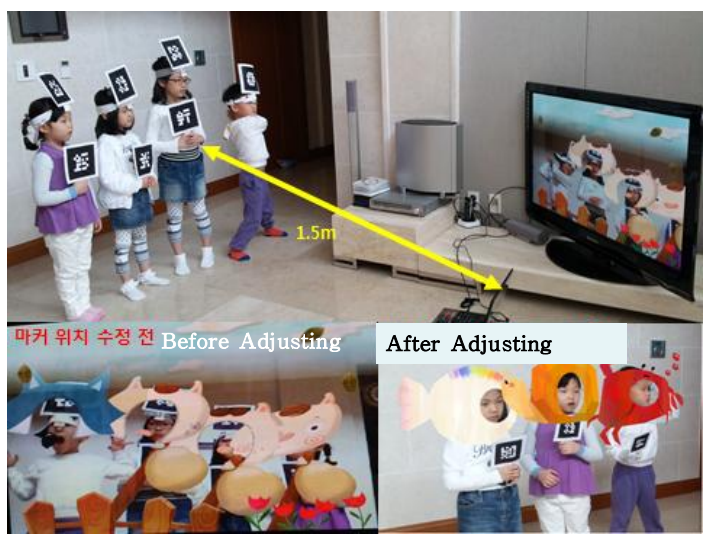

(Figure 2) Scene of the Robot Contents

\section{Experimental methodology}

After increasing the accuracy of face synthesis using QR markers on children (recorded by a robot's camera), two stories "Three Little Pigs" and "Mommy Fish, Where Are You?" were developed as shown in (Figure 3). Regarding these two stories, four contents areas were developed with pig and bubble sound effects. The contents were used with robots dressed up as pigs or in an under-the-sea theme for use in the experiment.

For each of the content areas, makeup to align with the dramatic play content and makeup not aligning with the content was applied, and seven children aged five to seven years were placed evenly in one of two groups (see Table 1). In (1), the experiment was stopped because of technical errors, and 
data for two participants were lost. Therefore, data from the experiment for 26 participants were collected at the end of the activity.

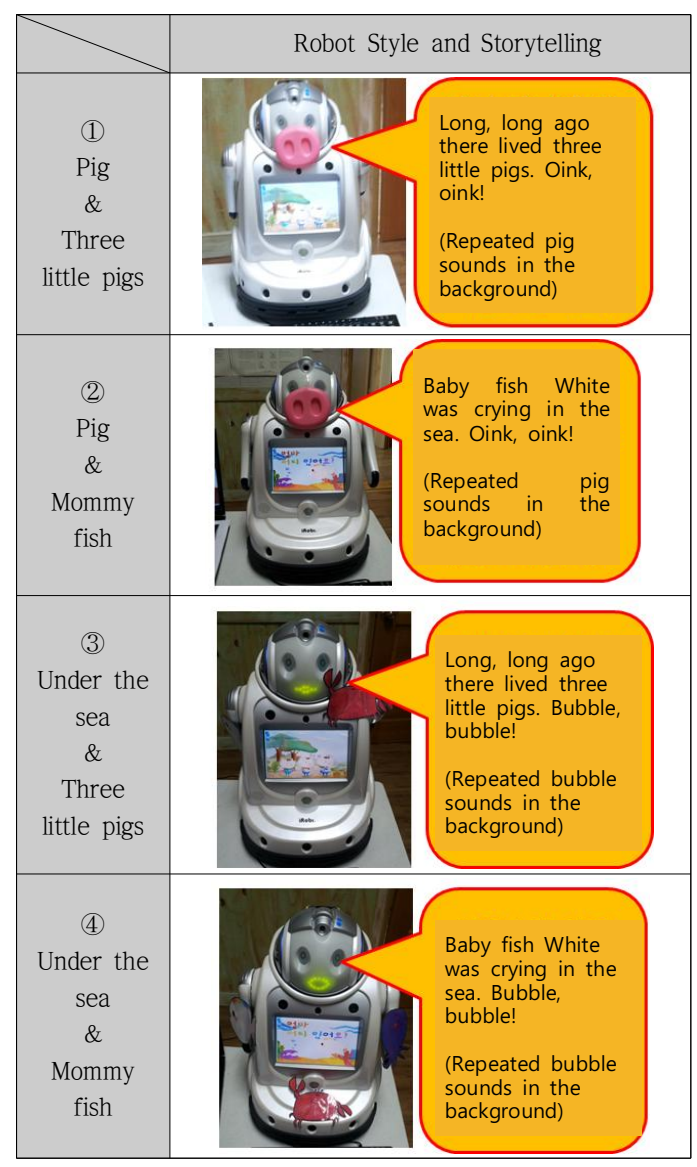

(Figure 3) Scene of the Robot Contents

\begin{tabular}{|c|c|c|c|}
\hline $\begin{array}{c}\text { Dramatic Play } \\
\text { Makeup }\end{array}$ & $\begin{array}{c}\text { Three little } \\
\text { pigs }\end{array}$ & $\begin{array}{c}\text { Mommy } \\
\text { fish }\end{array}$ & total \\
\hline Pig & 1 & 2 & \\
\hline Under the sea & 5 & 7 & 12 \\
\hline Total & 7 & 4 & \\
\hline
\end{tabular}

$<$ Table 1> Experimental Design

It was suggested that it is possible to use self-check interviews with participants who are age seven and up, based on extensive literature reviews on child-robot interaction (CRI) [6]; therefore, researchers used an image questionnaire when conducting one ${ }^{-}$on-one interviews to collect data, as shown in (Figure 4).

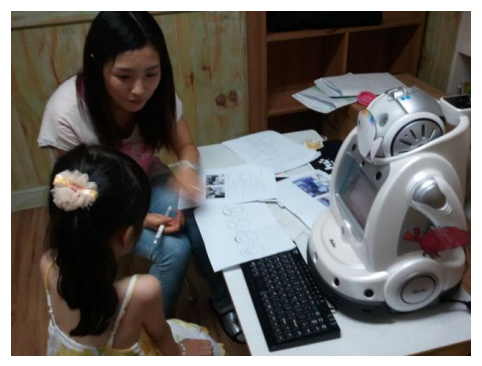

(Figure 4) Scene of Interview

\section{Analyzing interaction}

\subsection{Demographic analysis}

All children participating in the experiment were divided equally by gender $\langle$ Table $2>$, placing 13 in each group. The number of participants who had experience working with robots was two times more than participants with no experience. <Table $3>$ shows the age distribution for children who participated in the experiment.

\begin{tabular}{|c|c|c|c|}
\hline \multirow{2}{*}{ Robot experience } & \multicolumn{2}{|c|}{ Gender } & \multirow[b]{2}{*}{ Tota } \\
\hline & boy & girl & \\
\hline No & 4 & 5 & 9 \\
\hline Yes & 9 & 8 & 17 \\
\hline Total & 13 & 13 & 26 \\
\hline
\end{tabular}

$<$ Table 2> Distribution of experience with robots and gender of participants

\begin{tabular}{|c|c|c|c|c|}
\hline \multirow{2}{*}{ Robot experience } & \multicolumn{3}{|c|}{ Age } & \multirow{2}{*}{ Total } \\
\cline { 2 - 4 } & 5 & 6 & 7 & 9 \\
\hline No & 3 & 6 & 0 & 17 \\
Yes & 3 & 5 & 9 & 26 \\
\hline Total & 6 & 11 & 9 & 26 \\
\hline
\end{tabular}

$<$ Table 3> Distribution of experience with robots and age of participants

\subsection{Analysis of Children-Robot Interaction}

Participating children were asked to rate on a four-point scale their level of interest in dramatic play activities with robots, the 
appropriateness of robots' costumes and props, the level of intelligence the robot seemed to display, and how engaged they were personally in the activities.

$<$ Table 4> compares results for boy and girl participants, generally showing higher interest among boy participants, although the difference was not significant.

\begin{tabular}{|l|c|c|c|c|c|}
\hline & boy & girl & Average & T-value & $\mathrm{p}$-value \\
\hline Interest & 3.62 & 3.69 & 3.66 & -0.227 & 0.822 \\
\hline Costumes & 3.00 & 2.85 & 2.93 & 0.291 & 0.774 \\
\hline Intelligence & 3.08 & 3.08 & 3.08 & 0 & 1 \\
\hline Involvement & 3.39 & 3.27 & 3.33 & 0.307 & 0.762 \\
\hline
\end{tabular}

$<$ Table $4>$ Interaction results by gender

$<$ Table 5> compares results by participants' age groups, with younger groups showing relatively positive results at the significance level of $a=0.1$; significant results are shown in the interest and intelligence categories.

\begin{tabular}{|l|c|c|c|c|c|c|}
\hline & 5 & 6 & 7 & Mean & T-value & $\mathrm{p}$-value \\
\hline Interest & 4.00 & 3.91 & 3.11 & 3.65 & 3.406 & $0.051^{*}$ \\
\hline Costumes & 3.50 & 2.82 & 2.67 & 2.92 & 0.758 & 0.480 \\
\hline Intelligence & 3.83 & 3.18 & 2.44 & 3.08 & 3.332 & $0.054^{*}$ \\
\hline Involvement & 3.67 & 3.30 & 3.13 & 3.33 & 0.660 & 0.527 \\
\hline
\end{tabular}

"displays significant at the level $a=0.1$

$<$ Table $5>$ Interaction results by age groups

$<$ Table 6> compares existing experience with robot usage and at the significance level of $a=0.05$, and results based on interest and costumes are significant. In other words, children with no previous experience in robot usage showed greater levels of interest, and those who had such experience recognized differences in costumes. participants who had previous experience using robots felt that robots were not very smart and showed greater levels of involvement, but the result was not significant.

\begin{tabular}{|l|c|c|c|c|l|}
\hline \multirow{2}{*}{} & \multicolumn{2}{|c|}{$\begin{array}{c}\text { Robot usage } \\
\text { experience }\end{array}$} & Average & T-value & p-value \\
\cline { 2 - 6 } & No & Yes & & & \\
\hline Interest & 4.00 & 3.47 & 3.73 & 2.167 & $0.046^{* *}$ \\
\hline Costumes & 2.33 & 3.24 & 2.79 & -1.715 & $0.099^{*}$ \\
\hline Intelligence & 3.33 & 2.94 & 3.14 & 0.838 & 0.410 \\
\hline Involvement & 3.25 & 3.38 & 3.32 & -0.326 & 0.748 \\
\hline
\end{tabular}

<Table 6> Interaction results by participants' experiences with robots

Results from the analysis of interactions regarding the appropriateness of robot's costume are shown in $\langle$ Table 7$\rangle$. Groups of participants who had experimented with a similar robot and content scenario (1), (4)) and groups with different robot and content scenarios (2), (3)) in (Figure 3) showed a significant difference of $a=0.05$ just for costumes. Hence, the analysis indicates that it is important for children to see the resemblance between a robot's appearance and its contents.

\begin{tabular}{|l|c|c|c|c|l|}
\hline & Similarity & Difference & Average & T-value & $\mathrm{p}$-value \\
\hline Interest & 3.50 & 3.79 & 3.65 & -0.803 & 0.436 \\
\hline Costumes & 3.50 & 2.43 & 2.92 & 2.269 & $0.033^{* *}$ \\
\hline Intelligence & 3.08 & 3.07 & 3.08 & 0.026 & 0.979 \\
\hline Involvement & 3.32 & 3.35 & 3.34 & -0.077 & 0.939 \\
\hline
\end{tabular}

** displays significant at the level $\mathrm{a}=0.05$

$<$ Table $7>$ Interaction results by robot's style

Instead of referring to pictures from a picture book used in dramatic play activity, participants used drawings they had made to create contents (see Figure 4). 


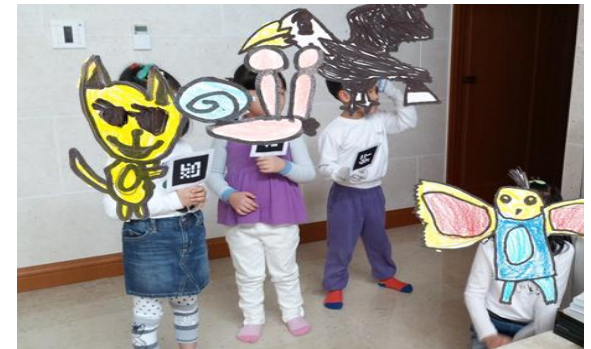

(Figure 4) Scene of Interview

Example pictures were used instead of participants' own pictures, and participants were interviewed about a hypothetical situation using the pictures drawn by themselves or their friends. <Table $8>$ shows that younger participants were more likely to prefer their own or their friends' pictures, but this difference was not significant. <Table 9> shows that girl participants tended to prefer their own or their friends' pictures, but this difference was not significant.

\begin{tabular}{|c|c|c|c|c|c|}
\hline $\begin{array}{c}\text { Age } \\
\text { years) }\end{array}$ & $\begin{array}{c}\text { Picture } \\
\text { book }\end{array}$ & $\begin{array}{c}\text { Own } \\
\text { picture }\end{array}$ & Total & $\chi^{2}$-value & p-value \\
\hline 5 & 1 & 5 & 6 & & \multirow{2}{*}{2.731} \\
\cline { 1 - 4 } 6 & 6 & 5 & 11 & 0.255 \\
\hline 7 & 5 & 4 & 9 & & \\
\hline Total & 12 & 14 & 26 & & \\
\hline
\end{tabular}

$<$ Table 8> Preferences by age group

\begin{tabular}{|c|c|c|c|c|c|}
\hline Gender & $\begin{array}{c}\text { Picture } \\
\text { book }\end{array}$ & $\begin{array}{c}\text { Own } \\
\text { picture }\end{array}$ & Total & $\chi^{2}$-value & p-value \\
\hline boy & 7 & 6 & 13 & & \multirow{2}{*}{0.431} \\
\hline girl & 5 & 8 & 13 & \multirow{2}{*}{0.619} & \\
\hline Total & 12 & 14 & 26 & & \\
\hline
\end{tabular}

$<$ Table 9> Preferences by gender

\section{Conclusion}

In this study, an analysis on basic interaction was conducted to extend dramatic play activity commonly used in kindergarten education facilities with augmented reality service using robots. In order to do so, pre-existing marker locations for augmented reality contents using robots were modified, and children's thoughts and reactions (regarding their levels of interest, appropriateness of costumes and props, intelligence, and involvement) were analyzed through interaction experiments and face-to-face interviews.

The boy participants showed positive reactions compared to girls, those with previous experience with robots found them to be less intelligent than those with no previous experience and showed higher levels of involvement, but not all results were significant. Additionally, younger participants showed a tendency to prefer their pictures or their friends' pictures over pictures from a book; but again, this does not seem to have significance. It is suspected that a participant's pictures were used in the initial experiment but replaced by friends' pictures during the interview process. Therefore, if participants' pictures had been collected and contents had been developed based on these for the actual experiment, it is predicted that the preference levels would have been higher.

One of the results with significance was that younger participants were more likely to find robots interesting and intelligent. Furthermore, participants with no previous experience with robots had relatively higher levels of interest in robots and tended to notice changes in robots' costumes.

A premise throughout this study was that utilizing dramatic play activity, QR code markers, and augmented reality to educate children seemed realistically applicable. Additionally, since children with previous experience working with robots find it important to see the resemblance between a robot's appearance, style, and content, these aspects must be taken into consideration when creating robot contents. 


\section{References}

[1] Brutsch, K., Schuler, T., Koenig, A., Zimmerli, L., Lunenburger, L., Riener, R., \& Meyer-Heim, A., "Inf luence of virtual reality soccer game on walking per formance in robotic assisted gait training for childre n”, Journal of Neuro Engineering and Rehabilitation, 7, pp.15-15, 2010.

[2] Han, J., Jo, M., Hyun, E., and So, H., "Examining young children's perception toward augmented reali ty-infused dramatic play. Educational Technology Research and Development”, Vol. 63, No. 3, pp.455-4 74, 2015, http://doi.org/10.1007/s11423-015-9374-9

[3] Jo, M., Han, J. and Hyun, E., "The Development of Robot and Augmented Reality based Contents and Instructional Model Supporting Children's Dramatic Play", Journal of the Korean Association of Informat ion Education, Vol. 17, No.4, pp.421-432, December 2014.

[4] Kim, S. and Han, J., "The Effect on the Contents of Self-Disclosure Activities using Ubiquitous Hom e Robots", Journal of the Korean Association of Info rmation Education, Vol.12, No.1, pp.57-63, 2008.

[5] Kong, S., "Device and Contents development for chil dren applying Mixed Reality Technology : Based on Children's toy 'Smart Car”, Journal of Digital Conte nts Society, Vol.17, No.5, pp.339-348, 2016.

[6] W Looge, "Research methodology in child-robot inte raction: a literature study", Master Thesis, Universi ty Twente, Nederland, 2016, Retrieved from http://e ssay.utwente.nl/70838/1/Looge_MA_BMS.pdf

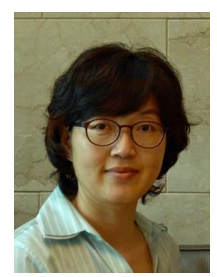

\section{Jeong-Hye Han}

1992

\author{
Chungbuk National
}

University (B.S. Degree).

1998 : Graduate School, Chungbuk

National University

(Ph.D Degree).

1999 2001: National Institute of Professional Administration (NIPA)

2011 2012: Visiting Scholar, H-STAR, Stanford University

2015 2017: Non-executive director of Korea Institute for Robot Industry Advancement (KIRIA)

2016 2019: Co-chair of Steering Committee for IEEE/ACM Human Robot Interaction

2001 Present: Professor of Computer Education at Cheongju National University of Education

Fields of interest: Robot Education, Children-Robot Interaction, Human-Robot Interaction 